\title{
TOXICITY OF SOME PLANT POWDER AGAINST LIFE STAGES OF RHIZOPERTHA DOMINICA (F.)
}

\author{
NOOR MAHAL, W. ISLAM ${ }^{1}$, K. A. M. S. H. MONDAL AND SELINA PARWEEN ${ }^{2}$ \\ Institute of Biological Sciences, University of Rajshahi, Rajshahi 6205, Bangladesh \\ ${ }^{2}$ Department of Zoology, University of Rajshahi, Rajshahi 6205, Bangladesh
}

\begin{abstract}
Toxicity of some important indigenous plant powder (Nigella sativa Linn., Murraya paniculata Linn., Jatropha curcas Linn., Eucalyptus camaldulensis Dehn., Datura metel Linn., and Vitex negundo Linn.) were used against different life stages of lesser grain borer, Rhizopertha dominica (Fabricius). Among them seed powder of $N$. sativa proved to be the most effective as toxicant. The results revealed to reduce the egg mortality, larval mortality and adult mortality of $R$. dominica significantly $(\mathrm{P}<0.001)$. The toxicity of botanicals were in the order of $N$. sativa $>M$. paniculata $>J$. curcas $>E$. camaldulensis $>D$. metel $>V$. negundo. All the plant powders were found to be effective for controlling stored product insect pests especially $R$. dominica and eco-friendly biopesticides.
\end{abstract}

Key words: Toxicity, Plant powder, $R$. dominica, Nigella sativa, Murraya paniculata, Jatropha curcas, Eucalyptus camaldulensis, Datura metel, Vitex negundo

\section{Introduction}

The hazardous effects of the conventional chemical insecticides have generated a sustained research for either safe alternative means of insect control or methods of reducing the amount of insecticides required for the pest management (Shaaya et al. 1997). Now a days there is an ever-increasing demand for herbal pesticides all over the world, because they are safe for non-target animals and human beings. They are also eco-friendly (Srinivasa et al. 1993). Over 2400 plant species are known to contain insecticidal and insect repellent constituents (Jacobson 1975), and botanical insecticides are locally available and are widely used to protect stored products from the damage caused by insects (Golob and Webley 1980), by the small-scale traditional farmers of Africa (Poswal and Akpa 1991) and Indian subcontinent (Rahman 1989). Tiwari (1994) evaluated 22 medicinal plant powders, ash of plant parts and sorbic acid as protectants of wheat against the infestation of a major insect pest of stored grains, Rhizopertha dominica (Coleoptera: Bostrichidae).

The present day research findings encourage to screen out the toxic effects of indigenous plants (different parts) to control the pests of stored grain and cereals. Consumer preference also showed avoidance towards the use of chemical neurotoxic insecticides in grain stores. Moreover. use of dry plant dusts are achieving interest to use as grain protectants, because these can easily be discarded by winnowing and washing.

\footnotetext{
${ }^{1}$ Corresponding author: mwislam2001@yahoo.com
} 
Paul et al. (2009) suggested to use dried plant materials because this is an easy mode of application to adopt for the farmer's level of grain storage. Plant powders showed effectiveness in controlling internal feeder of grains like Sitophilus zeamais Mots., and mortality and adult emergence of the weevil were dose dependent ranging from 1-5 g/20 $\mathrm{g}$ of grain; and no adverse effect of the plant was observed on the grain (maize) viability during 6 months storage (Enobakhare and Law-Ogbomo 2001).

In the present study an attempt was taken to investigate the effect of toxicity of seed powder of Nigella sativa (Linn), leaf powder of Murraya paniculata (Linn.), Jatropha curcas Linn., Eucalyptus camaldulensis Dehn, Datura metel Linn. and Vitex negundo Linn. against the egg, larval and adult stages of $R$. dominica (Coleoptera: Bostrichidae).

\section{Materials and Methods}

Collection of $R$. dominica: A culture of $R$. dominica was obtained from the Bangladesh Council of Scientific and Industrial Research (BCSIR) Laboratories, Rajshahi. The culture was maintained on white wheat grains at $30 \pm 0.5^{\circ} \mathrm{C}$ in an incubator without controlling humidity.

Rearing technique of $R$. dominica: A total of 1200 unsexed healthy beetles was collected from the stock culture, and divided them in three batches, each containing 400 adults of different ages. Each of these batches was kept in glass beaker $(400 \mathrm{ml})$ containing $200 \mathrm{~g}$ of cleaned and sterilized white wheat grains. Mouth of the beakers were covered with fine-meshed cloth to avoid escaping of the beetles. After 28-30 hours, the eggs were collected by passing the infested wheat grains through 500 and $80 \mu \mathrm{m}$ aperture sieves, which separated the grains and the adults respectively. The eggs were then transferred to glass petri dishes and incubated at room temperature of the laboratory.

The newly hatched larvae were placed in $500 \mathrm{ml}$ glass beakers containing approximately $200 \mathrm{~g}$ grains of sterilized wheat for one hundred larvae. The mouth of the beaker was covered by fine-meshed cloth and kept at room temperature, to ensure ample supply of beetles of known stage and age. After every 30 days the frass and faecal materials were removed by sieving, and freshly sterilized wheat grains were added to the culture. The amount of the wheat grain provided was increased proportionately each time.

Plant materials used: In this experiment dry seed powder of Nigella sativa Linn (Kalozira) and dry leaf powder of Murraya paniculata (Linn.) Jack, (Kamini), Jatropha curcas Linn., (Jamal Gota/Sada Jeol), Eucalyptus camaldulensis Dehn, Datura metel Linn., (Thorn apple) and Vitex negundo Linn., (nishinda) were used.

The cumin seeds were bought from the grocery shop, cleaned, dried and then grinded to fine powder with the help of an electric grinder.

Fresh mature leaves of the other three plants were collected from the botanical garden and the campus of the Rajshahi University, and also from nearby villages. The leaves were washed with tap water and dried under a shade at the roof of the laboratory for 3-7 days, depending on the crispy appearance of the leaves. The dried leaves were then grinded in an electric grinder, and the powder were passed through a $80 \mu \mathrm{m}$ sieve to 
collect the fine particles. The powder of the leaves were then stored separately in stoppered glass jars at room temperature.

The doses of the plant dusts were prepared as \% of weight/weight with wheat grain. Requisite weight of plant dusts was mixed with wheat grain in glass beakers, and shaked well. The plant powders were used within 7-10 days of preparation.

Experimentation : Prior to setting the experiments, pilot experiments were carried with the plant powder, for determining a dose fitting range by observing $0-100 \%$ of either eggs, larvae or adults (male and females separately) after 48 hours, by the treated grains. Then five sub lethal doses were selected separately for the egg, larval and adult stages, which were used in the present experiment.

Experiment I: Egg treatment: Sufficient number of adult $R$. dominica were collected from the stock culture and released in a beaker containing some fresh wheat grains. The adults were removed after 1-5-d, and the eggs were collected. The hatched larvae were removed every day over a period of 18 days. The number of hatched and unhatched eggs was recorded. The unhatched eggs became dark brown. The egg mortality data were correlated using Abbott's (1925) formula.

Fifty wheat grains treated with one of the dose of one of the plant powder taken in a petridish $(9 \mathrm{~cm}$ diam) were kept and 20 eggs were placed in it. Similarly, batches of 20 eggs were placed in separate petri dishes for each dose of each plant dust. Batches of 20 eggs were kept on untreated wheat grain as control. The doses used were $0.625,1.25,2.5$, 5.0 and $10.0 \% \mathrm{w} / \mathrm{w}$ for $N$. sativa seed powder and M. paniculata leaf powder, 1.25, 2.5, 5.010 .0 and $20.0 \% \mathrm{w} / \mathrm{w}$ for the leaf dust of $J$. curcas, Eucalyptus, D. metel and $V$. negundo. The hatched larvae from each treatment were removed out everyday over a period of 18 days. The number of hatched larvae and unhatched eggs were recorded.

Twenty eggs in five replicates were used for each dose of each plant powder, and also for the control. All the experiments were conducted at room temperature (mean $25 \pm 1{ }^{\circ} \mathrm{C}$ ).

Experiment II: Larval treatment: Newly hatched larvae of $R$. dominica were collected from the sub-cultures. Fifty larvae were placed in a glass petri dish $(9 \mathrm{~cm}$ diameter $)$ and provided with plant dust treated wheat flour of different doses. The doses used in the experiment were $1.25,2.5,5.0$ and $10.0 \% \mathrm{w} / \mathrm{w}$ of flour. Same number of neonates were also reared in untreated flour as control. Fifty larvae with five replicates were used for each dose of each plant powder, and also as control. The larval mortality was recorded after 48, 72 and 96 hours and finally after 10 days. The total number of dead larvae were counted. The experiments was conducted at room temperature (mean $25 \pm 1{ }^{0} \mathrm{C}$ ).

Experiment III. Adult mortality: Freshly laid eggs of $R$. dominica were collected from the stock culture, and kept in a glass beaker $(500 \mathrm{ml})$ containing $200 \mathrm{~g}$ cleaned and sterilized wheat grain. The eggs were allowed to hatch, and the larvae were reared up to pupation. After 24 days, the infested wheat were dissected carefully to collect live pupae. The pupae were sexed according to Halstead (1963), and the sexes were kept separately in beakers and allowed to emerge as adults. Mouth of the beakers were covered with fine cloth. 
After emergence the adults were provided with fresh wheat grains. Five-day old male and female adults were released on treated or untreated fresh wheat grain. The doses used were $1,2,4$ and $8 \% \mathrm{w} / \mathrm{w}$ of wheat. Ten adults were used for each dose of each plant dust. Same number of adults were raised on untreated wheat as control. All the experiments were conducted separately for male and female $R$. dominica in five replicates. The experiment was maintained at room temperature (mean $25 \pm 1^{\circ} \mathrm{C}$ ). Adult mortality was assessed from 1-5-d after exposure. The total mortal adults were counted.

\section{Results and Discussion}

Egg mortality: The eggs of $R$. dominica when exposed to different doses of powder of the studied plants for 18 days, the most toxic of them was the seed powder of $N$. sativa resulting in $93.33 \%$ larval mortality at the dose of $10 \% \mathrm{w} / \mathrm{w}$. At the same dose the degree of toxicity of the plant dusts were found as N. sativa $>M$. paniculata $>$ J. curcas $>$ E. camaldulensis $>V$. negundo $>$ D. metel (Table 1). The percentage of egg mortality increased with the increase of dose of each plant.

Table 1 . Toxicity of plant dusts on the eggs $(\mathrm{N}=100)$ of $R$. dominica at $18 \mathrm{~d}$ exposure.

\begin{tabular}{|c|c|c|c|}
\hline Plant used $^{1}$ & Dose $(\% \mathrm{w} / \mathrm{w})$ & No of mortal larvae (\%) & Corrected mortality of larvae (\%) \\
\hline Control $^{\mathrm{e}}$ & - & $10^{\mathrm{a}}$ & - \\
\hline \multirow[t]{5}{*}{ N. sativa $a^{\mathrm{a}}$} & 0.625 & $12^{\mathrm{a}}$ & 2.22 \\
\hline & 1.25 & $26^{\mathrm{b}}$ & 17.78 \\
\hline & 2.50 & $36^{\mathrm{c}}$ & 28.89 \\
\hline & 5.0 & $68^{\mathrm{de}}$ & 64.44 \\
\hline & 10.0 & $94^{\mathrm{e}}$ & 93.33 \\
\hline \multirow[t]{5}{*}{ M. paniculata ${ }^{\mathrm{b}}$} & 0.625 & $10^{\mathrm{a}}$ & 0.00 \\
\hline & 1.25 & $18^{\mathrm{a}}$ & 8.89 \\
\hline & 2.50 & $34^{\mathrm{c}}$ & 26.67 \\
\hline & 5.0 & $66^{\mathrm{dc}}$ & 62.22 \\
\hline & 10.0 & $88^{\mathrm{e}}$ & 86.87 \\
\hline \multirow[t]{5}{*}{ J. curcas $^{\mathrm{b}}$} & 0.625 & $08^{\mathrm{a}}$ & 0.00 \\
\hline & 1.25 & $16^{\mathrm{a}}$ & 6.67 \\
\hline & 2.50 & $32^{c}$ & 24.44 \\
\hline & 5.0 & $66^{\text {de }}$ & 62.22 \\
\hline & 10.0 & $88^{\mathrm{e}}$ & 86.67 \\
\hline \multirow[t]{5}{*}{ E. camaldulensis ${ }^{\mathrm{c}}$} & 0.625 & $12^{\mathrm{a}}$ & 2.22 \\
\hline & 1.25 & $20^{\mathrm{ab}}$ & 11.11 \\
\hline & 2.50 & $35^{\mathrm{c}}$ & 27.78 \\
\hline & 5.0 & $58^{\mathrm{d}}$ & 53.33 \\
\hline & 10.0 & $69^{\mathrm{de}}$ & 65.55 \\
\hline \multirow{5}{*}{ D. metel $^{\mathrm{d}}$} & 0.625 & $10^{\mathrm{a}}$ & 0.00 \\
\hline & 1.25 & $22^{\mathrm{b}}$ & 13.33 \\
\hline & 2.50 & $38^{\mathrm{bc}}$ & 31.11 \\
\hline & 5.0 & $56^{\mathrm{a}}$ & 51.11 \\
\hline & 10.0 & $68^{\text {de }}$ & 64.44 \\
\hline \multirow{5}{*}{ V. negundo ${ }^{\mathrm{d}}$} & 0.625 & $10^{\mathrm{a}}$ & 0.00 \\
\hline & 1.25 & $20^{\mathrm{ab}}$ & 11.11 \\
\hline & 2.50 & $35^{\mathrm{c}}$ & 27.78 \\
\hline & 5.0 & $58^{\mathrm{d}}$ & 53.33 \\
\hline & 10.0 & $69^{\mathrm{de}}$ & 65.55 \\
\hline
\end{tabular}

${ }^{1}$ NB. Means with same letter do not differ significantly $(\mathrm{P}<0.05)$. 
Larval mortality: Toxic effect of the plant powder on the larvae (1 to $10-\mathrm{d}$ old) of $R$. dominica was found to significantly different among the plants $(\mathrm{P}<0.001, \mathrm{~F}=11.10)$. Dusts of N. sativa, M. paniculata and J. curcas were more toxic than the other three plants (Table 2). These three plants showed more or less similar toxicity against the larvae.

Table 2. Toxicity of plant dusts against the larvae of $R$. dominica 10 days after treatment (DAT) $(\mathrm{N}=250)$.

\begin{tabular}{|c|c|c|c|c|}
\hline Plant dusts $^{2}$ & Dose $(\% \mathrm{w} / \mathrm{w})$ & $\begin{array}{l}\text { No of mortal larvae } \\
(\%)\end{array}$ & $\begin{array}{l}\text { Corrected mortality } \\
\text { of larvae }(\%)\end{array}$ & F-value \\
\hline Control $^{\mathrm{e}}$ & - & $6(2.4)^{\mathrm{a}}$ & - & \\
\hline \multirow[t]{4}{*}{ N. sativa ${ }^{\mathrm{a}}$} & 1.25 & $16(6.4)^{\mathrm{ab}}$ & 10.64 & \\
\hline & 2.50 & $23(9.2)^{\mathrm{c}}$ & 18.08 & \\
\hline & 5.0 & $31(12.4)^{d}$ & 26.59 & $\begin{array}{c}1 \mathrm{~F}=11.23 \\
\mathrm{P}<0.01\end{array}$ \\
\hline & 10.0 & $42(16.8)^{\mathrm{e}}$ & 38.29 & $\begin{array}{c}{ }^{2} \mathrm{~F}=11.10 \\
\mathrm{P}<0.01\end{array}$ \\
\hline \multirow[t]{4}{*}{ M. paniculata ${ }^{\mathrm{b}}$} & 1.25 & $15(6.0)^{\mathrm{ab}}$ & 9.57 & \\
\hline & 2.5 & $21(16.8)^{\mathrm{c}}$ & 15.96 & \\
\hline & 5.0 & $29(23.2)^{\mathrm{d}}$ & 24.47 & \\
\hline & 10.0 & $39(15.6)^{e}$ & 35.11 & \\
\hline \multirow[t]{4}{*}{ J. curcas $^{\mathrm{b}}$} & 1.25 & $16(6.4)^{\mathrm{ab}}$ & 10.64 & \\
\hline & 2.50 & $19(15.2)^{\mathrm{c}}$ & 13.83 & \\
\hline & 5.0 & $29(11.6)^{\mathrm{d}}$ & 24.47 & \\
\hline & 10.0 & $38(15.2)^{\mathrm{e}}$ & 34.04 & \\
\hline \multirow[t]{4}{*}{ E. camaldulensis ${ }^{\mathrm{c}}$} & 1.25 & $14(5.6)^{\mathrm{ab}}$ & 8.51 & \\
\hline & 2.5 & $16(6.4)^{\mathrm{ab}}$ & 10.64 & \\
\hline & 5.0 & $18(7.2)^{\mathrm{c}}$ & 12.77 & \\
\hline & 10.0 & $21(8.4)^{\mathrm{c}}$ & 15.96 & \\
\hline \multirow[t]{4}{*}{ D. metel $^{\mathrm{d}}$} & 1.25 & $10(4.0)^{\mathrm{a}}$ & 4.25 & \\
\hline & 2.5 & $12(4.8)^{\mathrm{ab}}$ & 6.38 & \\
\hline & 5.0 & $13(5.2)^{\mathrm{ab}}$ & 7.45 & \\
\hline & 10.0 & $16(6.4)^{\mathrm{ab}}$ & 10.64 & \\
\hline \multirow[t]{4}{*}{$V . n^{2} g u n d o^{\mathrm{d}}$} & 1.25 & $11(4.4)^{\mathrm{a}}$ & 5.32 & \\
\hline & 2.5 & $12(4.8)^{\mathrm{ab}}$ & 6.38 & \\
\hline & 5.0 & $14(5.6)^{\mathrm{ab}}$ & 8.51 & \\
\hline & 10.0 & $16(6.4)^{\mathrm{ab}}$ & 10.64 & \\
\hline
\end{tabular}

${ }^{2}$ NB. Means with same letter do not differ significantly $(\mathrm{P}<0.05)$.

Adult mortality: Adult mortality increased with time of exposure (1-5-d) and the males were more susceptible than the females (Tables 3 and 4). About 50\% mortality in both the sexes were obtained at highest dose. N. sativa, M. paniculata and $J$. curcas (8\%). N. sativa seed powder was found to be most toxic and the least toxicity was in D. metel leaf powder (Table 3 ). The degree of toxicity of the plants against the adult $R$. dominica was $N$. sativa $>M$. paniculata $>J$. curcas $>E$. camaldulensis $>V$. negundo $>$ D. metel. Mortality (\%) increased with the increase of dose and exposure period (Table 4). 
Table 3. Percent mortality of adult $R$. dominica treated with different plant dusts over a period of $1-5-\mathrm{d}$ exposure $(\mathrm{N}=50)$

\begin{tabular}{|c|c|c|c|}
\hline \multirow{2}{*}{ Treatment } & \multirow{2}{*}{$\begin{array}{l}\text { Dose }(\% \\
\mathrm{w} / \mathrm{w})\end{array}$} & \multicolumn{2}{|c|}{ Percentage mortality $($ Mean $\pm s d)$ from $1-5-d$} \\
\hline & & Male & Female \\
\hline Control $^{\mathrm{e}}$ & - & $34.63(6.93 \pm 3.13)^{\mathrm{a}}$ & $18.20(3.64 \pm 2.23)^{\mathrm{a}}$ \\
\hline \multirow[t]{4}{*}{ N. sativa $a^{\mathrm{a}}$} & 1 & $80.86(16.17 \pm 1.53)^{\mathrm{b}}$ & $90.73(18.15 \pm 1.74)^{\mathrm{b}}$ \\
\hline & 2 & $122.52(24.5 \pm 1.93)^{\mathrm{c}}$ & $117.25(23.45 \pm 1.39)^{\mathrm{c}}$ \\
\hline & 4 & $172.70(34.54 \pm 4.2)^{\mathrm{d}}$ & $161.47(32.29 \pm 4.67)^{\mathrm{d}}$ \\
\hline & 8 & $286.05(57.21 \pm 8.74)^{\mathrm{g}}$ & $274.82(54.96 \pm 8.47)^{\mathrm{f}}$ \\
\hline \multirow[t]{4}{*}{ M. paniculata ${ }^{\mathrm{b}}$} & 1 & $83.85(16.77 \pm 1.31)^{\mathrm{b}}$ & $80.85(16.17 \pm 1.53)^{\mathrm{b}}$ \\
\hline & 2 & $117.25(23.45 \pm 1.39)^{\mathrm{c}}$ & $102.55\left(20.51 \pm 1.56^{\mathrm{bc}}\right)$ \\
\hline & 4 & $167.60(33.52 \pm 4.75)^{\mathrm{d}}$ & $150.45(30.09 \pm 3.82)^{\mathrm{d}}$ \\
\hline & 8 & $268.00(53.60 \pm 7.94)^{\mathrm{d}}$ & $259.85(51.97 \pm 8.52)^{f}$ \\
\hline \multirow[t]{4}{*}{ J. curcas $^{\mathrm{b}}$} & 1 & $88.65(17.73 \pm 1.49)^{b}$ & $76.05(15.21 \pm 1.04)^{b}$ \\
\hline & 2 & $104.40(20.88 \pm 1.83)^{\mathrm{bc}}$ & $92.55(18.51 \pm 1.79)^{\mathrm{b}}$ \\
\hline & 4 & $146.60(29.32 \pm 4.19)^{\mathrm{d}}$ & $145.00(29.00 \pm 4.0)^{\mathrm{cd}}$ \\
\hline & 8 & $256.55(51.31 \pm 7.67)^{\mathrm{f}}$ & $252.40(50.48 \pm 8.02)^{\mathrm{f}}$ \\
\hline \multirow[t]{4}{*}{ E. camaldulensis ${ }^{\mathrm{c}}$} & 1 & $78.60(15.72 \pm 1.23)^{b}$ & $76.05(15.21 \pm 1.04)^{b}$ \\
\hline & 2 & $101.05(20.21 \pm 0.82)^{b c}$ & $93.00(18.60 \pm 1.82)^{\mathrm{b}}$ \\
\hline & 4 & $145.80(29.16 \pm 3.50)^{\mathrm{d}}$ & $136.65\left(27.33 \pm 3.65^{\mathrm{c}}\right)$ \\
\hline & 8 & $249.70(49.94 \pm 7.06)^{f}$ & $237.70(47.54 \pm 7.12)^{\mathrm{e}}$ \\
\hline \multirow[t]{4}{*}{ D. metel $^{\mathrm{d}}$} & 1 & $87.25(17.45 \pm 5.14)^{b}$ & $82.20(16.44 \pm 4.50)^{\mathrm{b}}$ \\
\hline & 2 & $116.00(23.20 \pm 7.48)^{\mathrm{b}}$ & $106.10(21.22 \pm 7.09)^{\mathrm{c}}$ \\
\hline & 4 & $146.85(29.37 \pm 9.3)^{d}$ & $145.35(29.07 \pm 8.93)^{\mathrm{cc}}$ \\
\hline & 8 & $172.20(34.44 \pm 10)^{\mathrm{d}}$ & $167.45(33.49 \pm 10.04)$ \\
\hline \multirow[t]{4}{*}{ V. negundo ${ }^{\mathrm{d}}$} & 1 & $69.25(13.85 \pm 1.57)^{\mathrm{b}}$ & $74.05(14.81 \pm 2.09)^{\mathrm{b}}$ \\
\hline & 2 & $100.20(20.04 \pm 2.90)^{\mathrm{bc}}$ & $94.70(18.94 \pm 3.16)^{b}$ \\
\hline & 4 & $153.85(30.77 \pm 5.77)^{\mathrm{d}}$ & $143.40(28.68 \pm 5.55)^{\mathrm{cd}}$ \\
\hline & 8 & $209.10(41.82 \pm 7.98)^{\mathrm{c}}$ & $202.55(40.51 \pm 7.63)^{\mathrm{c}}$ \\
\hline
\end{tabular}

NB. Means with same letter do not differ significantly $(\mathrm{P}<0.05)$.

Table 4. ANOVA showing the effect of plant dusts on the adult mortality (data based on Arcsine transformed value).

\begin{tabular}{lcc}
\hline Source of variation & \multicolumn{2}{c}{ F-value (significance level) } \\
\hline & Male & Female \\
Plants & $3.03(\mathrm{P}<0.05)$ & $2.98(\mathrm{P}<0.05)$ \\
Doses & $112.79(\mathrm{P}<0.01)$ & $107.42(\mathrm{P}<0.01)$ \\
Exposure period & $46.54(\mathrm{P}<0.01)$ & $45.96(\mathrm{P}<0.01)$ \\
\hline
\end{tabular}

The present results showed that the seed and leaf powders of the studied plants produced toxic effects against egg, larval and adults stages of $R$. dominica. About $50 \%$ mortality was achieved at doses $10 \%$ and $8 \% \mathrm{w} / \mathrm{w}$ in egg and adults stages respectively. The larval stage of the insect was comparatively tolerant than the other two life stages. The reason behind that the larvae are internal feeders of grain, so, very little amount flour might be consumed by the larvae at 10-d exposure. Secondly, the taste of the flour treated with plant dusts might acted as repellents, and the larvae consumed very little amount of the 
treated food which was not sufficient to produce higher percentage of mortal effect in them. Whereas, at lower dose $(8 \% \mathrm{w} / \mathrm{w})$ the adult mortality was achieved $>50 \%$ by three plant dusts (N. sativa, M. paniculata and J. curcas) at an exposure for $5-\mathrm{d}$, but $10 \% \mathrm{w} / \mathrm{w}$ doses of those three plant dusts resulted in only $\geq 16 \%$ larval mortality.

However, the leaf powders of some plants produce higher incidence of mortality against $R$. dominica adults, though the effect is more in grounded grain than in whole leaf powder of Punica granatum (the pomegrant) and Murraya koenigii at doses from 0.05 $1.0 \mathrm{~g} / 10 \mathrm{~g}$ of wheat and beater rice, and the adult mortality was $18-5 \%$ over control and $18-71 \%$ respectively. There are reports that dried leaf powders of Mentha spicata (Kashyap et al. 1974), Ocimum suave (Bekele et al. 1996) and Ocimum kilimandscharicum (Jembre et al. 1995) were toxic against some stored products insect pests. Leaf powder of Calotropis procera was toxic against the larvae of Tribolium castaneum (Jahan et al. 1991). Nukenine et al. (2007) had found that leaf powders of four African indigenous plants produced mortal effects in adult Sitophilus zeamais at doses of 5,10,20, and $40 \mathrm{~g} / \mathrm{kg}$ at an exposure of 32-d. Powders of black pepper seed (Piper nigrum) and red pepper fruit (Capsecum annuum) at doses from $0.15-0.5 \mathrm{w} / \mathrm{w}$ resulted in $90 \%$ and $60.23 \%$ adult mortality in $R$. dominica, and $90 \%$ and $59.22 \%$ mortality in adult S. granarious at 14-d exposure (Ashouri and Shayesteh 2009).

The present results and the published literature revealed that the powder of indigenous plants are toxic against the internal grain feeding insects like $R$. dominica and Sitophilus spp. A lower dose was found to be sufficient to produce mortal effects to all the feeding life stages of $R$. dominica at a comparatively longer exposure. The experimental plant powder can be mixed with wheat grain during storage, and can easily be washed out before use. Moreover, these plants are available throughout Bangladesh, and it is easy to dry the leaves or seed and ground into powder at home by the farmers. So, for farmers level of stocking this method is quite cost effective. The use of simple, effective crude botanicals, such as dusts/powder of plant parts is suited for grain protection by resource limited farmers in developing countries like Bangladesh where much materials can be processed at village level by using simple methods.

\section{References}

Abbot, W. S. 1925. A method of computing the effectiveness of an insecticide. J. econ. Ent. 18: 265-267.

Ashouri, S. and N. Shayesteh. 2009. Insecticidal activities of Black pepper and red pepper in powder form on adults of Rhizopertha dominica (F.) and Sitophilus granaries (L.). Pak. Entomol. 31 (2): 122-127.

Bekele, A. J., D. Obeng-Ofori and A. Hassanali 1996. Evaluation of Ocimum suave (Willd.) as a source of repellents, toxicants and protectants in storage against three stored product insect pests. Int. J. Pest Manag. 42 (2): 139-142.

Enobakhare, D. A. and K. E. Law-Ogbomo. 2001. Susceptibility of improved maize grain treated with leaf powder of Ocimum armygdalena to Sitophilus zeamais Mots. The Plant Scientist A 2(1/2): 48-62. 
Golob, P. and D. J. Webley. 1980. The use of plant materials as traditional protectants of stored products. Rep. Trop. Prod. Insts. 138 (4): 32.

Halstead, D. G. H. 1963. External sex differences in stored products Coleoptera. Bull. Ent. Res. 54: 119-134.

Jacobson, M. 1975. Insecticides from plants: A review of literature, 1954-71. USDA Agricultural Handbook 461pp.

Jahan, S., M. A. Mannan, A. R. Khan and P. Karmakar. 1991. Insecticidal effect of Akanda (Calotropis procera) on Tribolium confusum Duval (Coleoptera: Tenebrionidae). Bangladesh j. zool. 19 (2): 261-262.

Jembre, B., D. Obeng-Ofori, A. Hassanali and G. N. N. Nyamasyo 1995. Products derived from the leaves of Ocimum kilimandscharicum (Labiatae) as post-harvest grain protectants against the infestation of three major stored product insect pests. Bull. Ent. Res. 85: 361-367.

Kashyap, N. P., V. K. Gupta and A. N. Kaushal. 1974. Menthe spicata Linn. a promising protect ant to stored wheat against Sitophilus oryzae. Bull. Grain Tech. 12 (1): 41-44.

Nukenine, E. N., C. Adler and C.Reichmuth.2007. Efficacy evaluation of plant powders from Cameron as post-harvest grain protectants against the infestation of Sitophilus zeamais Motschulsky (Coleoptera: Curculionidae). J. Plant Diseases Prot. 114 (1): 30-36.

Rahman, M. M. 1989. Some promising physical, botanical and chemical methods for the protection of grain lehumes against bruchids in storage under Bangladesh condition. Proc. $2^{\text {nd. }}$ Int. Symp. Bruchids and Legumes (ISBL-2), September 6-9, 1989, Japan. K Fuji, A R Gatehouse, C D Johnson, R Mitchel and T Yosida eds. Pp. 63073.

Shaaya, E., M. Kostjukovski, J. Eilberg and C. Sukprakarn. 1997. Plant oils as fumigants and contact insecticides for the control of stored product insects. J. Stored Prod. Res. 33 (1): $7-15$.

Srinivasa, K. B., M. S. N. Murthy and T. B. Ramesh. 1993. Effect of botanicals on certain parasitoids. Presented at World Neem Conference. Neem and Environment, India 1993, 2: 1117. Oxford \& IBH Publ. Co. Pvt. Ltd.

Paul, U. V., J. S. Lossini, P. J. Edwards and A. Hilbeck. 2009. Effectiveness of products from four locally grown plants for the management of Acanthscelides obtectus (Say) and Zabrotes subfasciatus (Boheman ) (both Coleoptera: Bruchidae) in stored beans under laboratory and farm conditions in Northern Tanzania. J. Stored Prod. Res. 45: 97-107.

Poswal, M. A. T. and A. D. Akpa. 1991. Current trends in the use of traditional and organic methods for the control of crop pest and diseases in Nigeria. Trop. Pest Management 37: 329-333.

Tiwari, S. N. 1994. Efficacy of some plant products as grain protectants against Rhyzopertha dominica (Fab.) (Coleoptera: Bruchidae). Inter. J. Pest Management 40 (1): 94-97. 